\title{
PENGARUH KOMPOSISI BAHAN BAKU KOMPOS (SAMPAH ORGANIK PASAR, AMPAS TAHU, DAN RUMEN SAPI) TERHADAP KUALITAS DAN KUANTITAS KOMPOS
}

\author{
EFFECT OF COMPOST COMPOSITION OF RAW MATERIALS \\ (WASTE ORGANIC MARKET, SOYBEAN WASTE, AND RUMEN'S \\ COW) TO QUALITY AND QUANTITY OF COMPOST
}

\author{
Yommi Dewilda dan Firsti Listya Darfyolanda \\ Jurusan Teknik Lingkungan, Fakultas Teknik Universitas Andalas \\ email: yommi_tl@ft.unand.ac.id
}

\begin{abstract}
ABSTRAK
Penelitian ini mengkombinasikan sampah pasar (SP), ampas tahu (AT) dan rumen sapi (RS) sebagai bahan baku pengomposan. Tujuan penelitian untuk menganalisis pengaruh variasi komposisi bahan baku kompos sehingga diperoleh variasi yang optimum untuk proses pengomposan. Komposter terdiri dari 8 variasi yaitu variasi $1(60 \%$ SP; 40\% AT; 0\% RS), variasi $2(60 \%$ SP; 20\% AT; 20\% RS), variasi $3(50 \%$ SP; 30\% AT; $20 \%$ $R S)$, variasi $4(40 \% S P ; 40 \% A T ; 20 \% R S)$, variasi $5(70 \% S P ; 10 \% A T ; 20 \% S)$, variasi $6(60 \% S P ; 30 \% A T$; $10 \% R S)$, variasi $7(50 \%$ SP; $40 \%$ AT; $10 \%$ RS), variasi 8 (60\% SP; 20\% AT; 20\% RS; EM4). Metoda yang digunakan adalah pengomposan semiaerob. Hasil pengamatan terhadap kematangan kompos untuk parameter temperatur, pH, warna telah memenuhi standar SNI 19-7030-2004 dengan lama pengomposan 16-33 hari. Hasil analisis semua variasi kualitas kompos yaitu kadar air, C-organik, nitrogen, rasio C/N, phosfor, dan kalium, telah memenuhi standar SNI 19-7030-2004. Dari total bahan baku kompos sebanyak 3 liter, didapatkan kuantitas hasil kompos padat 0,45-0,87 liter dan kompos cair 0,45-1,2 liter. Berdasarkan hasil skoring terhadap kematangan, kualitas, dan kuantitas kompos, didapatkan variasi terbaik adalah variasi 5 (70\% SP; $10 \%$ AT; $20 \%$ RS).
\end{abstract}

Kata Kunci : $\quad$ Ampas tahu, kualitas kompos, kuantitas kompos, rumen sapi, sampah pasar

\begin{abstract}
This research combines market waste (SP), Soybeanwaste and the cow's rumen (RS) as raw material for composting. Composter consists of eight variations, variations 1 (60\% SP; 40\% AT; 0\% RS), variation of $2(60 \% \mathrm{SP} ; 20 \% \mathrm{AT}$; $20 \% \mathrm{RS})$, variation $3(50 \% \mathrm{SP} ; 30 \% \mathrm{AT} ; 20 \% \mathrm{RS})$, variations in 4 $(40 \% \mathrm{SP} ; 40 \% \mathrm{AT} ; 20 \% \mathrm{RS})$, variations in $5(70 \% \mathrm{SP} ; 10 \% \mathrm{AT} ; 20 \% \mathrm{~S})$, variations in $6(60 \% \mathrm{SP}$; $30 \% A T ; 10 \% R S)$, variations in $7(50 \%$ SP; $40 \%$ AT; $10 \% R S)$, variations of $8(60 \%$ SP; $20 \% A T$; 20\% RS; EM4). This study aimed to analyze the effect of variations composition of the compost raw materials in order to obtain a variation of the most optimum for composting. The methods used are composting semiaerob. The observation of the maturity of the compost to the parameters of temperature, $\mathrm{pH}$ and color meets the standards of SNI 19-7030-2004 with composting 16-33 days old. The results of the analysis of all variations of the water content of the compost quality, $C$-organic, nitrogen, C / N ratio, phosfor, and potassium, has met the standard of SNI 19-7030-2004. Of the total raw material compost as much as 3 liters, obtained quantity of solid compost and liquid compost from 0.45 to 0.87 liters of 0.45 to 1.2 liters. Based on the scoring result of the maturity, quality, and quantity of compost, obtained the best variation is a variation 5.
\end{abstract}

Keywords: Soybean waste, kompos quality and quantity, cow's rumen, market waste 


\section{PENDAHULUAN}

Semakin bertambahnya jumlah penduduk semakin meningkatkan jumlah timbulan sampah, terutama sampah organik. Pasar adalah salah satu penghasil sampah organik di Kota Padang. Salah satu cara mengurangi sampah organik dapat dilakukan dengan proses pengomposan.

Dalam proses pengomposan mikroba memerlukan kondisi lingkungan yang cocok untuk tumbuh dan memperbanyak diri selama degradasi bahan organik. Lingkungan yang optimal dapat dimodifikasi dengan menambahkan sumber nitrogen seperti ampas tahu untuk meningkatkan aktivitas mikroba. Abdullah (2004) merekomendasikan penggunaan ampas tahu dalam pengomposan dengan tujuan efisiensi pengomposan dan meningkatkan nilai ekonomis ampas tahu. Ampas tahu mengandung kadar C-organik sebesar 48,65\% dan kadar N-total 1,39\%. (Hindersah, 2012).

Rumen sapi merupakan limbah rumah pemotongan hewan berupa rumput yang belum terfermentasi dan tercerna sepenuhnya oleh hewan. Rumen sapi juga mengandung nutrisi yang digunakan oleh mikroba sebagai sumber energi. Rumen juga berfungsi sebagai bioaktivator untuk mempercepat proses pematangan kompos sampah organik.

Proses pengomposan dapat dipengaruhi oleh rasio C/N. Sampah organik di Pasar Bandar Buat Padang didominasi oleh sampah sayur dan buah. Sampah sayur dan buah memiliki rasio $\mathrm{C} / \mathrm{N}$ sekitar 25 dan ampas tahu memiliki $\mathrm{C} / \mathrm{N}$ sekitar 35. Oleh karena itu, dalam penelitian ini akan dilakukan kombinasi komposisi bahan baku optimum dalam pengomposan agar didapatkan hasil kompos yang memenuhi persyaratan sesuai SNI 197030-2004.
Pada penelitian ini dilakukan kombinasi komposisi sampah organik, ampas tahu, dan rumen sapi untuk mengetahui keefektifitasannya dalam pematangan kompos organik dan melihat bagaimana kualitas kompos yang dihasilkan berdasarkan SNI 197030-2004. Penelitian pembuatan kompos organik ini diharapkan dapat diaplikasikan oleh pemerintah dan masyarakat Kota Padang sehingga timbulan sampah Kota Padang yang masuk ke TPA Air Dingin bisa berkurang jumlahnya.

\section{METODOLOGI PENELITIAN}

\section{Tahapan Penelitian}

Tahapan penelitian mengenai pengaruh komposisi bahan baku (sampah pasar, ampas tahu dan rumen sapi) terhadap kualitas dan kuantitas kompos dengan uraian sebagai berikut:

\section{Persiapan Penelitian}

\section{Persiapan Alat}

Komposter yang digunakan merupakan modifikasi dari komposter hasil rancangan dari Pusat Penelitian dan Pengembangan Pemukiman di bawah Balitbangepartemen Pekerjaan Umum, Bandung. Perbandingan komposter yang digunakan dalam penelitian ini 1:10 dari komposter rancangan pusat penelitian tersebut.Untuk lebih jelasnya dapat dilihat pada gambar 1 .

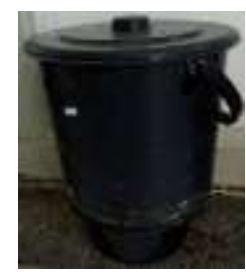

Gambar 1 Komposter 
Alat uji kematangan dan kuantitas kompos Peralatan yang digunakan untuk pengujian kematangan dan kuantitas kompos berupa $\mathrm{pH}$ meter, termometer, penggaris dan gelas ukur plastik. Untuk lebih jelasnya dapat dilihat pada Tabel 1.

\section{Persiapan Bahan}

Persiapan bahan meliputi persiapan bahan baku yang terdiri dari sampah pasar, ampas tahu dan rumen sapi. Total bahan baku yang dibutuhkan untuk masing-masing variasi pada penelitian ini berjumlah 3 liter. Variasi bahan baku dapat dilihat pada tabel 2 .

\section{Tabel 1 Peralatan Uji Kematangan dan Kuantitas Kompos}

\begin{tabular}{|l|l|l|}
\hline No. & \multicolumn{1}{|c|}{ Item } & \multicolumn{1}{|c|}{ Fungsi } \\
\hline 1. & pH meter & Mengukur pH kompos \\
\hline 2. & Termometer & $\begin{array}{l}\text { Mengukur temperatur } \\
\text { kompos }\end{array}$ \\
\hline 3. & Penggaris & $\begin{array}{l}\text { Mengukur tingkat reduksi } \\
\text { kompos }\end{array}$ \\
\hline 4. & $\begin{array}{l}\text { Gelas ukur } \\
\text { plastik }\end{array}$ & $\begin{array}{l}\text { Mengukur volume kompos } \\
\text { yang dihasilkan }\end{array}$ \\
\hline
\end{tabular}

Tabel 2 Komposisi Bahan Baku Kompos

\begin{tabular}{|l|l|l|l|l|l|l|}
\hline & \multicolumn{3}{|l|}{ Komposisi (\%) } & \multicolumn{2}{l|}{ Berat (L) } \\
\hline Variasi & SP & AT & RS & SP & AT & RS \\
\hline 1 & 60 & 40 & 0 & 1,8 & 1,2 & 0 \\
\hline 2 & 60 & 20 & 20 & 1,8 & 0,6 & 0,6 \\
\hline 3 & 50 & 30 & 20 & 1,5 & 0,9 & 0,6 \\
\hline 4 & 40 & 40 & 20 & 1,2 & 1,2 & 0,6 \\
\hline 5 & 70 & 10 & 20 & 2,1 & 0,3 & 0,6 \\
\hline 6 & 60 & 30 & 10 & 1,8 & 0,9 & 0,3 \\
\hline 7 & 50 & 40 & 10 & 1,5 & 1,2 & 0,3 \\
\hline 8 & \multicolumn{7}{|l}{$\begin{array}{l}\text { Variasi 2 dengan } \\
\text { penambahan EM4 }\end{array}$} & 1,8 & 0,6 & 0,6 \\
\hline
\end{tabular}

\section{Proses Pengomposan}

Berdasarkan penelitian (Isroi, 2008) diketahui bahwa terdapat 2 parameter penting dalam menentukan pemilihan bahan baku yaitu: rasio $\mathrm{C} / \mathrm{N}$ dan kadar air bahan baku. Uji pendahuluan dilakukan untuk mengetahui kondisi optimum bahan kompos untuk dilakukan proses pengomposan dilihat dari parameter rasio $\mathrm{C} / \mathrm{N}$ dan kadar air masing-masing variasi kompos.

\section{Proses Pengomposan}

Langkah-langkah pembuatan kompos yaitu:

1. Sampah organik yang telah dicacah dimasukkan ke dalam wadah komposter yang telah dipersiapkan;

2. Ampas tahu dan Rumen sapi segar ditambahkan pada sampah organik sesuai variasi yang telah ditentukan, Variasi 8 dibuat sebagai variasi tambahan untuk melihat perbedaan kematangan, kualitas, dan kuantitas kompos dengan penambahan EM4 namun tidak dimasukkan dalam penilaian pemilihan komposisi optimum;

3. Kemudian diaduk sampai homogen. Pengadukan dilakukan dua kali 24 jam untuk mengeluarkan gas-gas yang terbentuk;

4. Pengecekan terhadap temperatur, kelembaban, $\mathrm{pH}$, dan tingkat reduksi kompos dilakukan setiap hari. Kemudian dicatat hasilnya. Pengecekan dilakukan sebelum pengadukan dilakukan;

5. Dilakukan pengujian kematangan, kualitas, dan kuantitas kompos. Sebelum pengujian kualitas kompos dilakukan pengayakan agar didapatkan hasil kompos yang lebih halus.

\section{Penelitian Utama}

\section{Uji Kematangan Kompos}

Pengecekan uji kematangan kompos dilakukan setiap hari. Parameter yang diuji adalah temperatur, tekstur dan warna, bau, dan $\mathrm{pH}$ kompos. Parameter yang diukur didasarkan pada SNI 19-7030-2004. Kompos dinyatakan matang apabila sudah mencapai temperatur air tanah yaitu $\leq 30^{\circ} \mathrm{C}$, ph mencapai $\mathrm{pH}$ netral $(6,8$ $-7,49)$, tekstur dan warna sudah menyerupai tanah, dan bau sudah berbau tanah (SNI 197030-2004). Pengadukan terhadap kompos dilakukan setiap hari sampai kompos matang.

\section{Pengukuran Kuantitas Kompos}


Uji kuantitas kompos dilakukan terhadap kompos padat dan kompos cair yang dihasilkan. Hasil kompos dihitung dengan menggunakan satuan volume. Kompos padat yang telah diayak dan kompos cair yang dihasilkan dari proses pengomposan diukur volumenya menggunakan gelas ukur. Kompos padat yang didapatkan memiliki struktur halus dan homogen. Struktur yang kasar dan bahan asing yang masih tertinggal dalam proses pengomposan tidak lolos ayakan merupakan residu kompos.

\section{Pengukuran Kualitas Kompos}

Pengukuran kualitas kompos dilakukan di Laboratorium Buangan Padat Jurusan Teknik Lingkungan Universitas Andalas. Prinsip pengukuran masing-masing parameter menggunakan metode sebagai berikut:

a. Penentuan C Organik dengan metode Walkey Black

b. Pengukurun Nitrogen dengan metode Titrimetri

c.

enentuan fosfor $\left(\mathrm{P}_{2} \mathrm{O}_{5}\right)$ dengan Metode Spektrofotometri

d.

enentuan kalium $\left(\mathrm{K}_{2} \mathrm{O}\right)$ dengan metode Spektrofotometri Serapan Atom (SSA).

\section{Pengolahan dan Analisis Data}

Data yang dianalisis pada penelitian ini meliputi analisis terhadap pengaruh penambahan ampas tahu dan rumen sapi pada bahan baku kompos. Analisis ini dilakukan berdasarkan lamanya waktu pengomposan, banyaknya reduksi bahan yang terjadi dan persentase reduksi bahan. Uji tingkat kematangan kompos dilakukan dengan temperatur, warna, tekstur, $\mathrm{pH}$ kompos tersebut. Uji kualitas kompos kematangan kompos dilakukan dengan menguji kadar air, parameter C-Organik, Nitrogen, rasio $\mathrm{C} / \mathrm{N}$, Fosfor dan Kalium. Kualitas hasil kompos ini dibandingkan dengan SNI 19-7030-2004 tentang Spesifikasi Kompos dari Sampah Organik Domestik.

Selanjutnya dilakukan analisis dan pembahasan mengenai kematangan, kualitas dan kuantitas kompos. Dalam analisis ini juga dilakukan pemilihan komposisi bahan baku kompos yang optimum dengan menggunakan sistem skoring. Sistem skoring ini dilakukan dengan memberikan penilaian kepada masingmasing variasi bahan baku kompos yang telah ditentukan. Untuk variasi dengan nilai skor tertinggi merupakan variasi yang terbaik.

\section{Penilaian Kematangan Kompos}

Penentuan skoring untuk parameter kematangan kompos adalah sebagai berikut:

1. Lama waktu pengomposan

Penilaian lamanya waktu pengomposan dilakukan berdasarkan hasil kompos yang paling cepat matang sampai yang paling lama matang dengan sistem ranking. kemudian diberi nilai berdasarkan ranking tersebut.

2. Temperatur dan $\mathrm{pH}$

P Penilaian Temperatur dilakukan berdasarkan SNI 19-7030-2004, dimana temperatur matang memiliki suhu yang

$\mathrm{P}$ sama dengan air tanah atau tidak melebihi $30^{\circ} \mathrm{C}$. Penilaian $\mathrm{pH}$ dilakukan berdasarkan standar minimum dan maksimum $\mathrm{pH}$ akhir kompos, yaitu 6,8-7,49.

Nilai $1 *=$ diberikan apabila variasi memenuhi baku mutu SNI 19-7030-2004;

Nilai $0^{*} \quad=$ diberikan apabila variasi tidak memenuhi baku mutu SNI 19-70302004

3. Reduksi bahan

Penilaian reduksi bahan dilakukan berdsarkan hasil kompos yang paling banyak dihasilkan dengan sistem ranking kemudian diberi nilai berdasarkan ranking tersebut. Ranking tertinggi nilainya 8 dan rangking terendah nilainya 1 .

4. Tekstur dan warna 
Penilaian Tekstur dan warna dilakukan berdasarkan SNI 19-7030-2004, dimana tekstur dan warna kompos matang adalah seperti tanah. Sistem penilaiannya sama dengan sistem penilaian untuk parameter temperatur dan $\mathrm{pH}$.

\section{Penilaian Kuantitas Kompos}

Penilaian kuantitas kompos di berikan berdasarkan jumlah kompos yang dihasilkan pada masing-masing variasi.

a. Nilai 3 diberikan kepada variasi yang memiliki jumlah kompos diatas 1 Liter untuk kompos padat dan kompos cair;

b. Nilai 2 diberikan kepada variasi yang memiliki jumlah kompos antara 0,5 sampai 1 Liter untuk kompos padat dan kompos cair;

c. Nilai 1 diberikan kepada variasi yang memiliki jumlah kompos dibawah 0,5 Liter untuk kompos padat dan kompos cair.

\section{HASIL DAN PEMBAHASAN}

Penelitian ini membahas tentang komposisi bahan baku kompos yang optimum dilihat dari kualitas dan kuantitas kompos.

\section{Uji Pendahuluan}

Rasio $\mathrm{C} / \mathrm{N}$ merupakan perbandingan antara kadar karbon dan nitrogen yang terdapat dalam kompos yang berguna bagi mikroorganisme untuk proses dekomposisi senyawa organik. Berdasarkan uji pendahuluan yang telah dilakukan, bahan baku yang digunakan telah memenuhi rentang $\mathrm{C} / \mathrm{N}$ bahan baku pengomposan yang baik yaitu antara 25-35 (Tarigan, 2012). Semua variasi variasi komposisi bahan baku memiliki rasio $\mathrm{C} / \mathrm{N}$ 30-31. Rasio C/N untuk variasi kompos pada uji pendahuluan dapat dilihat pada Gambar 2.

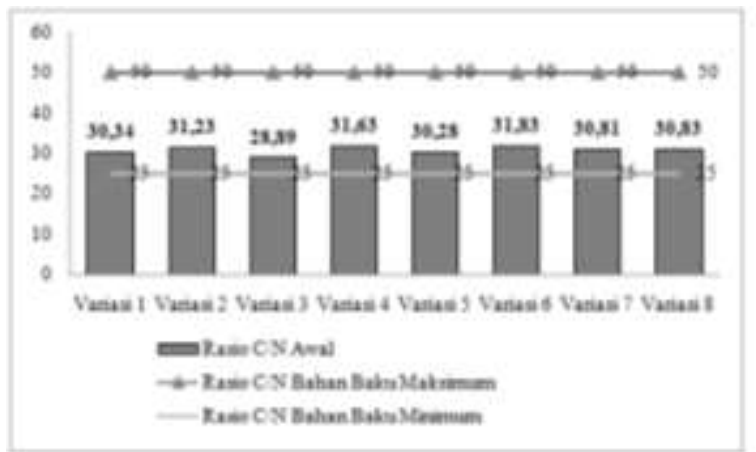

\section{Gambar 2 Nilai Rasio C/N Awal Pengomposan}

Kadar air penting dalam proses pengomposan karena kelembaban atau kadar air mempengaruhi aktivitas mikroorganisme di dalam kompos. Kadar air awal pengomposan harus berada pada rentang 40-60\%. Nilai kadar air awal semua variasi kompos memenuhi standar yang ditentukan yaitu 40$41 \%$. Semakin banyak penambahan sampah pasar maka kadar air semakin tinggi. Kadar air awal bahan kompos dapat dilihat pada gambar 3.

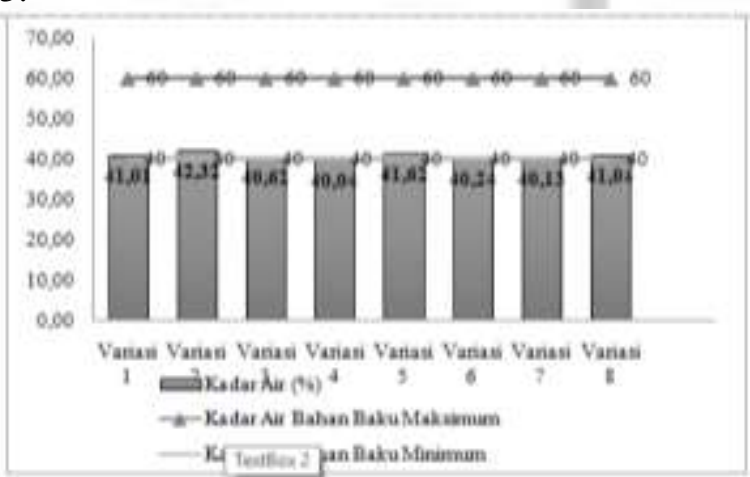

Gambar 3 Kadar air Awal Pengomposan

Analisis Pengaruh Pemanfaatan Ampas Tahu dan Rumen Sapi

Analisis pengaruh pemanfaatan limbah rumen sapi yang digunakan sebagai bahan baku sekaligus bioaktivator dalam pengomposan sampah organik, dapat dilihat dari lama waktu pengomposan dan persentase reduksi sampah organik yang terjadi selama proses pengomposan. 


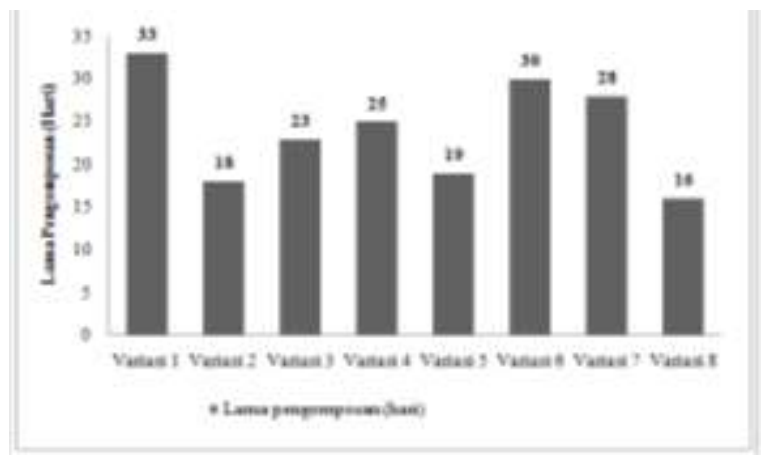

Gambar 4 Lama Waktu Pengomposan

Lama waktu pengomposan yang terjadi yaitu 16-33 hari yang dapat dilihat pada Gambar 4.

Perbedaan lama waktu pengomposan yang terjadi disebabkan kandungan mikroorganisme yang terdapat pada masing-masing komposter berbeda-beda. Komposter 1 merupakan komposter yang hanya berisikan sampah dan ampas tahu tanpa adanya penambahan bioaktivator. Mikroorganisme yang terdapat didalamnya akan secara bertahap untuk mulai tumbuh dan beradaptasi secara alami sehingga memerlukan waktu pengomposan yang cukup lama.

Berbagai bahan organik yang terdapat pada ampas tahu yang didegradasi bersama dengan sampah pasar akan menambah beban penguraian sehingga proses pengomposan berlangsung lama. Semakin banyak bahan organik yang akan diuraikan oleh mikroba maka aktivitas mikroba semakin meningkat sehingga menimbulkan panas yang berlebihan, panas tersebut akan berubah menjadi uap air. Uap air yang terbentuk tidak dapat terbebas ke udara karena komposter dalam keadaan tertutup. Hal ini menyebabkan uap air yang terbentuk kembali lagi ke tumpukan kompos, sehingga kompos menjadi basah dan kompos semakin lembab, semakin tinggi kelembaban maka suplay oksigen akan berkurang sehingga menurunkan aktivitas mikroorganisme dalam menguraikan bahan baku kompos, sehingga proses pengomposan semakin lama. Kelembaban yang tinggi dapat diatasi dengan pengadukan tapi ampas tahu memiliki sifat mudah dibasahi dan mudah menyerap air sehingga air tetap terperangkap didalam komposter.
Bakteri yang bekerja pada penguraian ampas tahu adalah bakteri hidrolitik yang berperan memecah molekul organik komplek (protein, selulosa, lignin), asidogenik fermentatif, asetogenik dan bakteri metanogen yang terbentuk secara alami yang mengubah $\mathrm{CO}_{2}$ menjadi metan (Haryoto, 2005). Seharusnya hal ini menyebabkan pengomposan berjalan cepat, namun karena bakteri pada ampas tahu aktif pada minggu kedua (Haryoto, 2005) sehingga proses pengomposan berjalan lambat. Bakteri pada ampas tahu aktif pada minggu kedua juga dijelaskan pada penelitian Arifin (2012), aktivitas mikroorganisme dalam mendekomposisikan bahan organik terjadi pada hari kedelapan hingga hari ke 15 .

Efektifitas pemanfaatan limbah rumen sapi dilihat dari tingkat reduksi yang terjadi selama proses pengomposan sampah organik. Tingkat reduksi diketahui sejalan dengan waktu kematangan kompos (Isroi, 2008). Kompos dikatakan matang apabila tingkat reduksinya telah mencapai $20-40 \%$ atau volumenya telah berkurang sepertiga dari volume awal kompos. Perbandingan perubahan tingkat reduksi pengomposan dapat dilihat pada Gambar 5 .

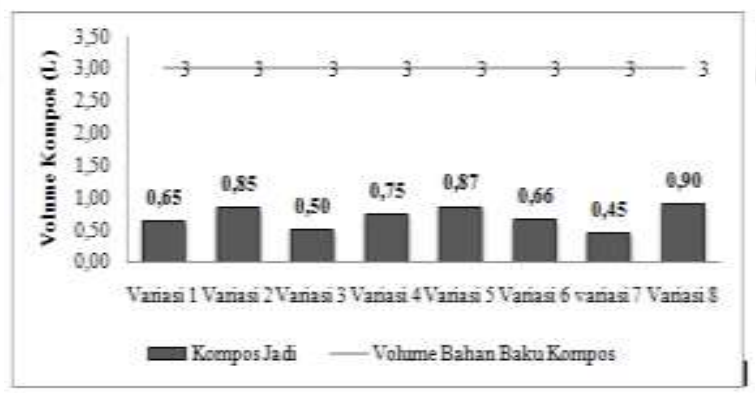

Gambar 5 Reduksi Bahan

Besarnya reduksi bahan seiring dengan banyaknya penambahan ampas tahu yang merupakan sumber mikroba degradasi bahan organik. semakin banyak penampahan ampas tahu maka tingkat reduksi semakin besar. Kecilnya tingkat reduksi pada komposter 8 tidak mempengaruhi hasil pengomposan karena penyusutannya telah memenuhi standar, volumenya telah berkurang sepertiga dari volume awal. Dalam hal ini tingkat reduksi yang paling optimum adalah variasi 8 dengan tingkat reduksi $70 \%$. Hal ini disebabkan tingkat reduksi yang terlalu tinggi 
akan mengurangi kuantitas kompos yang dihasilkan.

\section{Uji Kematangan Kompos}

Kematangan kompos diperlukan untuk menentukan lama pengomposan.Untuk itu diperlukan analisis pemantauan parameter temperatur, $\mathrm{pH}$, tekstur dan warna serta bau. Uji ini dilakukan tiap hari sampai kompos matang.

Temperatur merupakan salah satu indikator yang menandakan perubahan aktivitas mikroorganisme dalam menguraikan bahan organik. Kompos dinyatakan matang jika temperatur $\leq 30^{\circ} \mathrm{C}$. Temperatur memainkan peranan penting dalam pengomposan. Temperatur adalah indikator dari dinamika aktivitas mikrobiologi dalam pengomposan. Temperatur diukur setiap hari selama masa pengomposan. Tingkat panas dingin yang terjadi disebabkan oleh aktivitas mikroorganisme pada bahan baku kompos. Pada penelitian ini, kenaikan temperatur dilihat dari terdapatnya uap air ditutup komposter. Uap air dihasilkan dari panas pada proses pengomposan. Pada penelitian ini, temperatur akhir kompos berkisar antara 26$27^{\circ} \mathrm{C}$. Berdasarkan SNI 19-7030-2004 tentang standar kualitas kompos, nilai maksimum temperatur tidak lebih dari $30^{\circ} \mathrm{C}$. Pada penelitian ini temperatur berkisar antara 2627 , temperatur pengomposan telah memenuhi nilai standar.

Selama proses pengomposan akan terjadi perubahan warna pada bahan kompos. Awal proses pengomposan bahan kompos berwarna hijau dan setelah mencapai tahap kematangan akhir akan berwarna hitam. Menurut SNI 197030-2004 warna akhir kompos ketika matang adalah hitam. Seluruh variasi kompos mengalami perubahan tekstur dan warna setelah hari ke 3. Pada penelitian ini variasi sampah organik, ampas tahu, dan rumen sapi yang dikomposkan mengalami perubahan warna menjadi kehitaman sangat lama. Perubahan warna tercepat terjadi pada komposter 8 setelah hari ke-13. Perubahan warna terlama terjadi pada komposter 1 tanpa penambahan rumen sapi yaitu setelah hari ke29. Hal ini disebabkan tidak adanya bioaktivator sehingga proses penguraian berlangsung lama. Lama terjadinya perubahan warna dikarenakan warna dasar bahan yang masih kelihatan kehijauan dan tekstur masih mirip dengan tekstur aslinya (Tarigan, 2012).

$\mathrm{pH}$ merupakan salah satu indikator kematangan kompos, $\mathrm{pH}$ berpengaruh terhadap mikoorganisme dalam mendekomposisi bahan organik. Proses pengomposan akan menyebabkan perubahan pada bahan organik dan $\mathrm{pH}$ bahan itu sendiri.

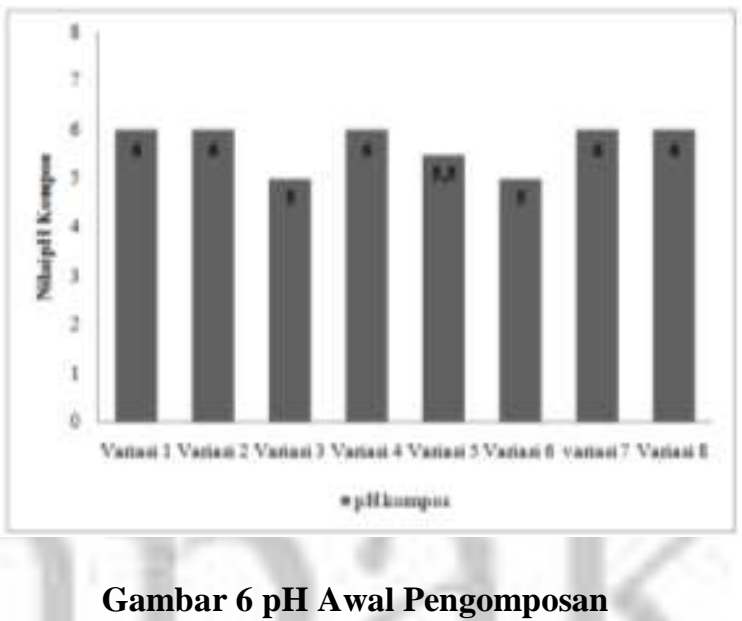

$\mathrm{pH}$ awal pengomposan dapat dilihat pada gambar 6. Pada awal pengomposan semua variasi bahan kompos berada pada $\mathrm{pH}$ yang relatif asam yakni 5 dan 6 . Hal ini disebabkan oleh penambahan ampas tahu yang memiliki $\mathrm{pH}$ asam antara 4-5 kemudian $\mathrm{pH}$ akan mengalami peningkatan seiring berjalannya proses dekomposisi oleh senyawa organik.

Kenaikan $\mathrm{pH}$ yang terjadi karena pada proses pengomposan akan dihasilkan amoniak dan gas nitrogen sehingga nilai $\mathrm{pH}$ berubah menjadi basa. Pada saat terjadinya kenaikan temperatur, aktivitas bakteri mesofilik terhenti dan kemudian digantikan oleh kelompok bakteri termofilik. Bersamaan dengan pergantian ini, maka amoniak dan gas nitrogen akan dihasilkan sehingga nilai $\mathrm{pH}$ berubah menjadi basa. Sejalan dengan aktivitas mikroorganisme di dalam bahan, maka temperatur akan mulai naik dan akhirnya menghasilkan asam organik. Hal ini akan mengakibatkan nilai $\mathrm{pH}$ menurun. Kedua, aktivitas bakteri termofilik terjadi kenaikan 
temperatur, dimana bakteri mesofilik terhenti kemudian digantikan oleh bakteri termofilik. Bersamaan dengan pergantian ini maka amoniak dan nitrogen dihasilkan sehingga nilai $\mathrm{pH}$ akan berubah menjadi basa. $\mathrm{pH}$ akhir pengomposan pada penelitian ini 7,22-7,28 yang dapat dilihat pada gambar 7 .

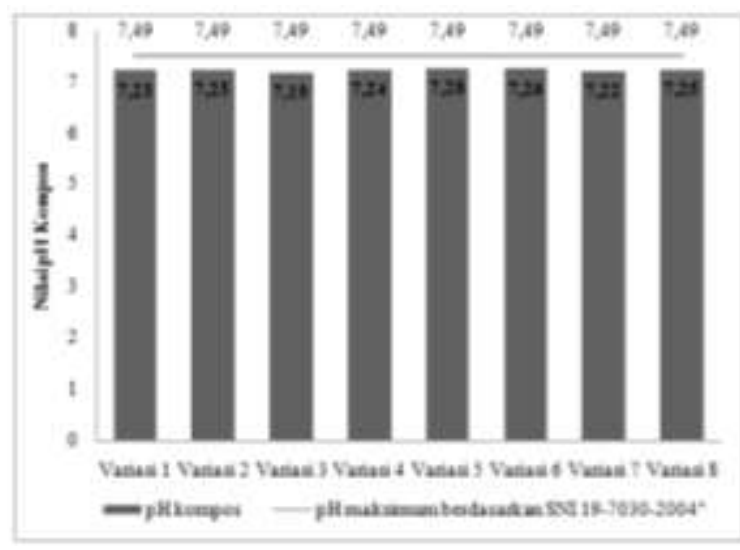

Gambar 7 pH Akhir Pengomposan

Tabel 3 Rekapitulasi Kematangan Kompos

\begin{tabular}{|c|c|c|c|c|c|c|}
\hline No & Variasi & $\begin{array}{c}\text { Lama Waktu } \\
\text { Pengomposan } \\
\text { (Hari) }\end{array}$ & $\begin{array}{c}\text { Persentase } \\
\text { Reduksi Bahan } \\
(\mathbf{\%})\end{array}$ & $\begin{array}{c}\text { Temperatur } \\
\text { Akhir }\left({ }^{\circ} \mathbf{C}\right)\end{array}$ & $\mathbf{p H}$ & $\begin{array}{c}\text { Tekstur dan } \\
\text { Warna }\end{array}$ \\
\hline 1 & variasi 1 & 33 & 78 & 26,5 & 7,23 & seperti tanah \\
\hline 2 & variasi 2 & 18 & 72 & 26,5 & 7,25 & seperti tanah \\
\hline 3 & variasi 3 & 23 & 83 & 27 & 7,19 & seperti tanah \\
\hline 4 & variasi 4 & 25 & 75 & 27 & 7,24 & seperti tanah \\
\hline 5 & variasi 5 & 19 & 71 & 27 & 7,28 & seperti tanah \\
\hline 6 & variasi 6 & 30 & 78 & 27 & 7,26 & seperti tanah \\
\hline 7 & Variasi 7 & 28 & 85 & 26,5 & 7,22 & seperti tanah \\
\hline 8 & Variasi 8 & 16 & 70 & 26 & 7,25 & seperti tanah \\
\hline
\end{tabular}

\section{Kualitas Kompos}

Semua variasi kompos memenuhi syarat kualitas kompos sesuai SNI 19-7030-2004.
Rekapitulasi hasil uji kualitas kompos dapat dilihat pada Tabel 4.

Tabel 4 Rekapitulasi Kualitas Kompos

\begin{tabular}{|c|c|c|c|c|c|r|r|}
\hline No & Item & $\begin{array}{c}\text { Kadar Air } \\
(\boldsymbol{\%})\end{array}$ & $\begin{array}{c}\text { C-Organik } \\
(\boldsymbol{\%})\end{array}$ & $\begin{array}{c}\text { Nitrogen } \\
(\boldsymbol{\%})\end{array}$ & $\mathbf{C / N}$ & $\begin{array}{c}\text { Phosfor } \\
(\boldsymbol{\%})\end{array}$ & $\begin{array}{c}\text { Kalium } \\
(\boldsymbol{\%})\end{array}$ \\
\hline & Baku Mutu & $<50$ & $9,8-32$ & $>0,4$ & $10-20$ & $>0,1$ & $>0,2$ \\
\hline 1 & Variasi 1 & 20,83 & 28,32 & 1,46 & 19,35 & 0,26 & 0,42 \\
\hline 2 & Variasi 2 & 20,42 & 28,74 & 1,47 & 19,50 & 0,23 & 0,57 \\
\hline 3 & Variasi 3 & 19,03 & 18,36 & 1,34 & 13,75 & 0,41 & 0,46 \\
\hline 4 & Variasi 4 & 21,29 & 25,10 & 1,41 & 17,81 & 0,30 & 0,40 \\
\hline 5 & Variasi 5 & 24,62 & 28,27 & 1,56 & 18,18 & 0,34 & 0,53 \\
\hline 6 & Variasi 6 & 23,78 & 28,25 & 1,44 & 19,66 & 0,44 & 0,83 \\
\hline 7 & Variasi 7 & 22,80 & 25,30 & 1,40 & 18,06 & 0,34 & 0,46 \\
\hline 8 & Variasi 8 & 20,98 & 25,00 & 1,43 & 17,48 & 0,26 & 0,72 \\
\hline
\end{tabular}




\section{Kuantitas Kompos}

Analisis kuantitas kompos meliputi kuantitas terhadap volume kompos padat dan kompos cair. Kompos padat merupakan kompos matang yang telah diayak menggunakan alat pengayak dengan ukuran ayakan 7,5 $\mathrm{mm}$. Kompos cair yang diukur merupakan cairan yang ditampung di bawah komposter selama proses pengomposan. Rekapitulasi kuantitas kompos dapat dilihat pada Tabel 5.

Tabel 5 Rekapitulasi Kuantitas Kompos

\begin{tabular}{|c|c|c|c|c|c|c|}
\hline \multirow{2}{*}{ No } & \multirow{2}{*}{ Variasi } & $\begin{array}{c}\text { Bahan } \\
\text { Baku } \\
(\mathbf{L})\end{array}$ & $\begin{array}{c}\text { Kompos Matang (Sebelum } \\
\text { Diayak) (L) }\end{array}$ & $\begin{array}{c}\text { Kompos Padat } \\
(\mathbf{L})\end{array}$ & $\begin{array}{c}\text { Kompos Cair } \\
(\mathbf{L})\end{array}$ & $\begin{array}{c}\text { Resid } \\
\mathbf{u}(\mathbf{L})\end{array}$ \\
\hline 1 & Variasi 1 & 3 & 1 & 0,65 & 1,2 & 0,35 \\
\hline 2 & Variasi 2 & 3 & 1,05 & 0,85 & 0,45 & 0,20 \\
\hline 3 & Variasi 3 & 3 & 0,85 & 0,50 & 0,65 & 0,35 \\
\hline 4 & Variasi 4 & 3 & 1 & 0,75 & 0,7 & 0,25 \\
\hline 5 & Variasi 5 & 3 & 1,02 & 0,87 & 0,6 & 0,15 \\
\hline 6 & Variasi 6 & 3 & 0,86 & 0,66 & 1,05 & 0,20 \\
\hline 7 & Variasi 7 & 3 & 0,7 & 0,45 & 0,95 & 0.25 \\
\hline 8 & Variasi 8 & 3 & 1 & 0,90 & 0,47 & 0,1 \\
\hline
\end{tabular}

Penentuan Komposisi Bahan Baku Optimum

Penentuan komposisi bahan baku optimum dilakukan dengan menggunakan sistem skoring dan Ranking. Rekapitulasi hasil skoring masing-masing variasi kompos dapat dilihat pada Tabel 6 .

Tabel 6 Rekapitulasi Skoring Kompos

\begin{tabular}{|c|c|c|c|c|c|}
\hline No & Variasi & $\begin{array}{c}\text { Total Skoring } \\
\text { Pemantauan } \\
\text { Kematangan Kompos }\end{array}$ & $\begin{array}{c}\text { Total Skoring } \\
\text { Kualitas Kompos }\end{array}$ & $\begin{array}{c}\text { Total Skoring } \\
\text { Kuantitas Kompos }\end{array}$ & $\begin{array}{c}\text { Total } \\
\text { Skor }\end{array}$ \\
\hline 1 & Variasi 1 & 7 & 10,5 & 5 & 22,5 \\
\hline 2 & Variasi 2 & 16 & 12 & 3 & 31 \\
\hline 3 & Variasi 3 & 10 & 21,5 & 4 & 35,5 \\
\hline 4 & Variasi 4 & 12 & 14 & 4 & 37,5 \\
\hline 5 & Variasi 5 & 16 & 17,5 & 5 & 34 \\
\hline 6 & Variasi 6 & 9 & 20 & 3 & 27 \\
\hline 7 & Variasi 7 & 7 & 17 & 3 & 41,5 \\
\hline 8 & Variasi 8 & 19 & 19,5 & & \\
\hline
\end{tabular}


Variasi 8 dibuat sebagai variasi tambahan untuk melihat perbedaan kematangan, kualitas, dan kuantitas kompos dengan penambahan EM4 namun tidak dimasukkan dalam penilaian pemilihan komposisi optimum. Berdasarkan total hasil skor yang didapat, variasi 5 dengan komposisi $70 \%$ sampah pasar, $10 \%$ ampas tahu dan $20 \%$ rumen sapi, merupakan komposisi optimum dengan skor 37,5.

\section{SIMPULAN}

Kombinasi sampah pasar, ampas tahu dan rumen sapi sebagai bahan baku pengomposan berpengaruh terhadap proses pengomposan;

Berdasarkan uji kematangan dan kualitas kompos, semua variasi komposisi bahan baku telah memenuhi standar SNI 19-7030-2004.

Kuantitas kompos padat berkisar antara 0,45 0,87 Liter, sedangkan kompos cair berkisar antara $0,45-1,2$ Liter dengan tingkat reduksi bahan antara $70-85 \%$;

Beasarkan hasil skoring dari segi kematangan, kualitas, dan kuantitas kompos, komposisi pada variasi 5 (70\% sampah pasar : $10 \%$ ampas tahu : $20 \%$ rumen sapi) merupakan variasi komposisi terbaik yang dapat digunakan sebagai bahan baku pengomposan

\section{DAFTAR PUSTAKA}

Center for Policy and Implementation Studis (CPIS).(1992). Buku Panduan Teknik Pembuatan Kompos dari Sampah, Teori, dan Aplikasi. Jakarta: Center for Policy and Implementation Studis (CPIS).

Pembalikan. Prosiding SNTK TOPI 2011. Jurusan Teknik Kimia. Universitas Riau. Pekanbaru.

Haryoto, dkk. 2005. Pembuatan Tahu. Edisi Teknologi Pengolahan Pangan. Yogyakarta

Hindersah. 2011. Pemanfaatan Limbah Tahu dalam pengomposan sampah rumah tangga untuk meningkatkan kualitas mikrobiologi kompos. Universitas Padjajaran

Isroi. 2008. Kompos. Bogor: Peneliti pada Balai Penelitian Bioteknologi Perkebunan Indonesia

Sembiring, P., 2010. Pengantar Ruminologi. Medan. USU Press

SNI 19-7030-2004 tentang Standar Kualitas Kompos

Tarigan., 2012. Pembuatan Pupuk Organik Cair Dengan Memanfaatkan Limbah Padat Sayuran Kubis (Brassica Aleracege. L) Dan Isi Rumen Sapi 